\title{
Physicochemical and geotechnical properties of an ash-slag mixture deposited on a landfill in terms of its use in engineering
}

\author{
Artur Szwalec ${ }^{1}$, Andrzej Gruchot ${ }^{2}$, Paweł Mundała ${ }^{1}$, Eugeniusz Zawisza ${ }^{2}$, \\ Renata Kędzior ${ }^{1}$
}

${ }^{1}$ University of Agriculture in Krakow, Department of Ecology, Climatology and Air Protection; al. A. Mickiewicza 24/28,30-059 Krakow, Poland; e-mail: rmmundal@cyf-kr.edu.pl

${ }^{2}$ University of Agriculture in Krakow, Department of Hydraulic Engineering and Geotechnics; al. A. Mickiewicza 24/28, 30-059 Krakow, Poland

\begin{abstract}
(C) 2017 Authors. This is an open access publication, which can be used, distributed and reproduced in any medium according to the Creative Commons CC-BY 4.0 License requiring that the original work has been properly cited.
\end{abstract}

Received: 11.04.2017; accepted: 10.08.2017

\begin{abstract}
Coal combustion ash-slag mixtures have been deposited in landfills in Poland for decades. At the same time, there is a shortfall in the amount of available materials related to the construction and modernisation of transportation infrastructure. Thus, a typical landfill of a power station was chosen and the aim of the study was to assess the suitability of an ash-slag landfill mixture for construction engineering purposes. The following physicochemical analyses were conducted: $\mathrm{pH}$, specific electrical conductivity and determination of the leachability of basic $(\mathrm{Ca}, \mathrm{Na}, \mathrm{K}$ and $\mathrm{Mg})$ and trace elements $(\mathrm{Cd}, \mathrm{Pb}, \mathrm{Cr}, \mathrm{Zn}$ and $\mathrm{Cu})$. The content of selected basic and trace elements were determined in the eluates by FAAS and standard methods were applied for geotechnical analyses. The most likely conditions were assumed to the model. The mixture will not jeopardize surface water quality in terms of the concentrations of basic, hazardous or priority elements. The content of these elements also does not exceed permissible concentrations for groundwater. The conductance and $\mathrm{pH}$ of the eluates are in compliance with current laws. The solid mixture has favourable geotechnical parameters which are significantly dependent on moisture content. The slope stability calculations for embankments created from the mixture at optimum moisture content and high compaction $\left(I_{s} \geq 0.95\right)$ indicate that they will be stable even in the case of high gradients (1:1.5). The slopes will be unstable in conditions of submersion, which should not occur if we assume the embankment will be used for passive flood protection. The mixture is particularly suitable for the purposes of earth structures, provided that they are isolated from water.
\end{abstract}

Keywords: ash-slag mixture, reuse of coal combustion waste, embankment, shear strength reduction method

\section{INTRODUCTION}

The power industry generates over 18 million $\mathrm{Mg}$ of waste annually, accounting for about $14.5 \%$ of the total volume of waste produced in Poland. For many years this waste was placed in landfills, usually by hydraulic methods. According to the Central Statistical Office (Environment... 2016), about 294.1 million $\mathrm{Mg}$ of coal combustion waste remains in landfills. The economic use and exploitation of such waste is becoming increasingly common. Fine waste such as fly ash is mainly used to produce cement and construction materials, and to a limited extent also for agricultural purposes, while coarser waste, such as ash-slag mixtures, is used in road construction, land reclamation and to fill in excavations (Góra 1986, Galos \& Uliasz-Bocheńczyk 2005, Ram et al. 2007, 
Żygadło \& Woźniak 2009, Fenelonov et al. 2010, Hirajima et al. 2010, Haustein \& Quand 2011, Kušnierová et al. 2011, Jayaranjan et al. 2014). These types of waste are also mentioned as a source of rare earth metals (Hycnar \& Tora 2015, Jarosiński 2016). Despite such numerous possibilities, not all power plant waste deposited in landfills is utilized. Such measures often require the construction of new installations, which entails high investment costs. Therefore, to minimize the cost of recycling the waste, local use should be considered.

The aim of the study was to assess the suitability of an ash-slag mixture from the former Skawina Power Plant landfill for construction engineering on the basis of physicochemical and geotechnical tests and calculations of water flow through a model of an embankment and slope stability.

\section{MATERIALS AND METHODS}

\section{Landfill description}

The former Czech Power Company (CEZ) Skawina Power Plant waste landfill in Kopanka village near Skawina town, Krakow region, south of Poland (Fig. 1A) is located in one of the excavations remaining after the exploitation of natural aggregates, having operated since 1975 . In the geological structure of the terrain, the superficial layer consists of quaternary formations represented by river sediments (coarse sands and gravel, covered in some places with alluvial soils, interbedded with loam, silt loam and mud sludge). Tertiary forms are represented by impermeable clay, silty clay or heavy silt loam. The mean coefficients of permeability range from $3.4 \cdot 10^{-11}$ to $2.61 \cdot 10^{-2} \mathrm{~m} \cdot \mathrm{s}^{-1}$. In addition, significant self-sealing of the landfill bottom has resulted from the consolidation of the material during its deposition. The landfill, together with the accompanying infrastructure, occupies an area of $68 \mathrm{ha}$, and the area of basins C-2 and C-3 is 47.3 ha (Fig. 1). The capacity of the landfill is about 6.8 million $\mathrm{m}^{3}$ (including embankments), while the used capacity is about 5 million $\mathrm{m}^{3}$ (Referat... 2012). Deposition of coal power plant waste in the landfill was terminated in 2015. One problem with the potential utilization of the deposited waste is the lack of an adequate technical infrastructure enabling its use for engineering purposes.
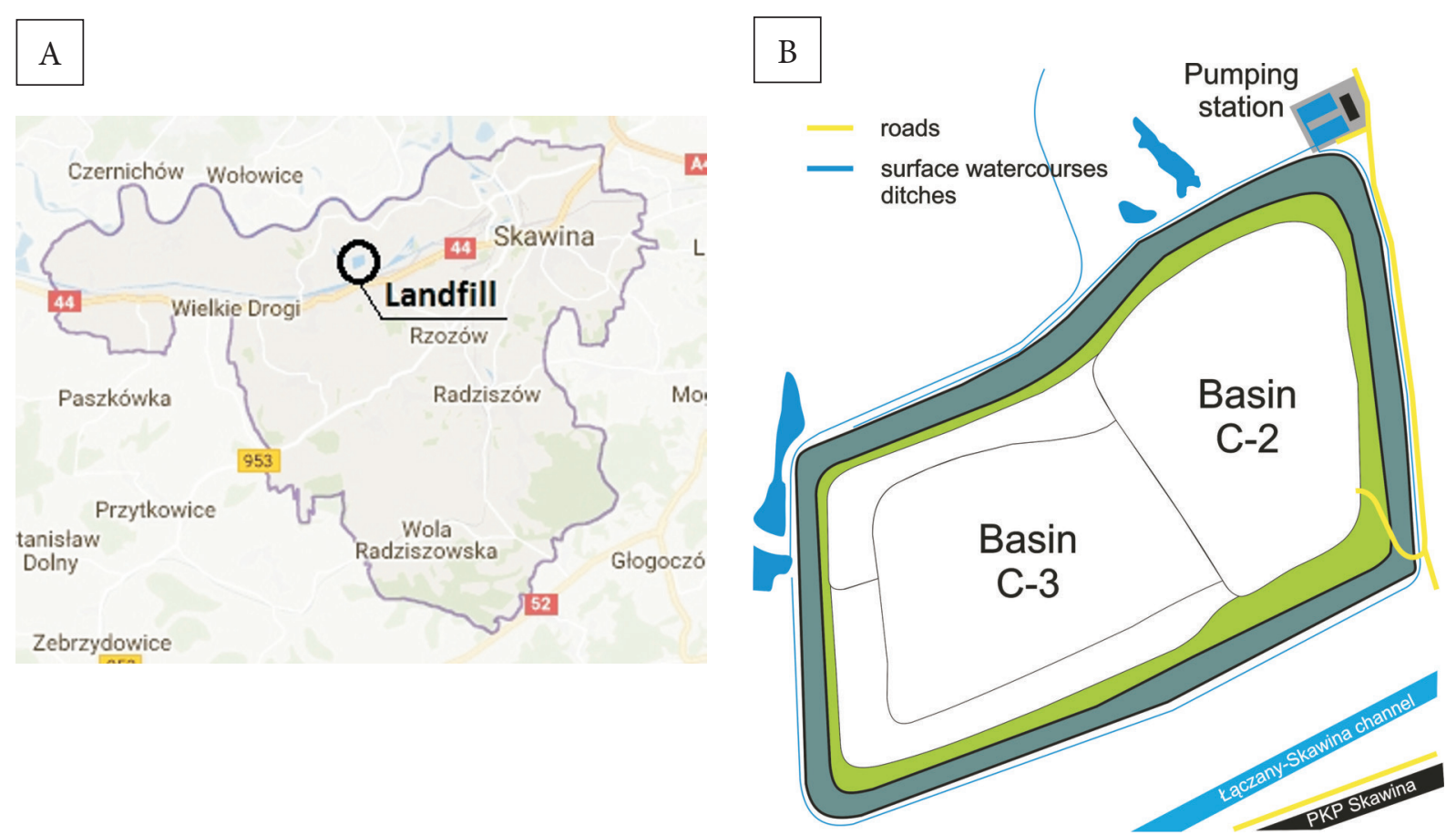

Fig. 1. Location of the former CEZ Skawina Power Plant waste landfill (A) and its division into basins (B) 


\section{Sample collection}

The material for the study was collected from the landfill in the autumn of 2015. Waste samples were collected from 20 sampling points on the surface of basins C-2 and C-3 (10 for each basin). Each sampling point was an area of about $25 \mathrm{~m}^{2}$. A soil sampler was used to collect seven samples from the superficial layer $(0-50 \mathrm{~cm})$. Following homogenization, these constituted an averaged sample with a combined weight of about $15 \mathrm{~kg}$. From each averaged sample, an analytical sample of $1.5 \mathrm{~kg}$ was taken for chemical analysis, and the remaining portion was used for the analysis of geotechnical properties.

\section{Chemical and geotechnical analyses}

The physicochemical analyses included the determination of the leachability of basic elements $(\mathrm{Ca}, \mathrm{Na}, \mathrm{K}$ and $\mathrm{Mg})$ and trace elements $(\mathrm{Cd}, \mathrm{Pb}$, $\mathrm{Cr}, \mathrm{Zn}$ and $\mathrm{Cu}$ ) from the ash-slag mixture according to standard PN-EN 12457-4:2006. Aqueous extracts from the waste were prepared in a 1:10 ratio (waste: water). The $\mathrm{pH}$, specific electrical conductivity and content of selected basic and trace elements were determined in the eluates by flame atomic absorption spectrometry (FAAS) on a Solaar M6 spectrophotometer from Unicam.

Basic geotechnical properties and compaction parameters were determined by standard methods. Grain-size composition was determined by the sieve method for grains and particles greater than $0.063 \mathrm{~mm}$ and by the hydrometer method for smaller particles. The specific density was determined in distilled water using a volumetric flask. The optimum moisture content and maximum dry density were determined in a Proctor apparatus in a $2.2 \mathrm{dm}^{3}$ cylinder with compaction energy of $0.59 \mathrm{~J} \cdot \mathrm{cm}^{-3}$. Shear strength parameters were tested in a standard direct shear apparatus in a box with a $12 \times 12 \mathrm{~cm}$ cross-section and sample height of $7.7 \mathrm{~cm}$, with 5 intermediate frames forming a shearing zone $10 \mathrm{~mm}$ high. Material with a grain size of less than $10 \mathrm{~mm}$ was used for the tests, assuming that the diameter of the maximum grain would correspond to the height of the shearing zone. Samples were formed in the box of the apparatus with optimum moisture content to obtain a degree of compaction of $I_{S}=0.95$ and sheared with and without submersion of the shearing zone at a shear rate of $0.2 \mathrm{~mm} \cdot \mathrm{min}^{-1}$.

The coefficient of permeability was determined for two vertical directions of water flow through the sample, 'bottom to top' and 'top to bottom', in a ZWk2 apparatus. The measurements were made after the flow was stabilized, with a constant hydraulic drop. Material with close to optimal moisture content was compacted in the cylinder of the apparatus to obtain a degree of compaction of $I_{S}=0.95$.

\section{Calculations and assumption to the model}

Calculations of steady and unsteady flow and stability were performed for an embankment model with a height of $6 \mathrm{~m}$ and a top width of $5 \mathrm{~m}$ (Fig. 2) on a substrate of the ash-slag mixture. The inclination of the upstream and downstream slope was 1:1.5 and $1: 3$, and the groundwater table was $1.0 \mathrm{~m}$ below the surface. The calculations were made by finite element method using Geo5 software, separately for a computational model with a slope gradient of 1:1.5 for 3,118 elements and 5,653 nodes, and for a model with a slope gradient of 1:3 for 4,696 elements and 8,605 nodes. For the stability calculations, Coulomb-Mohr's elastic perfectly plastic model and the shear strength reduction method were applied.

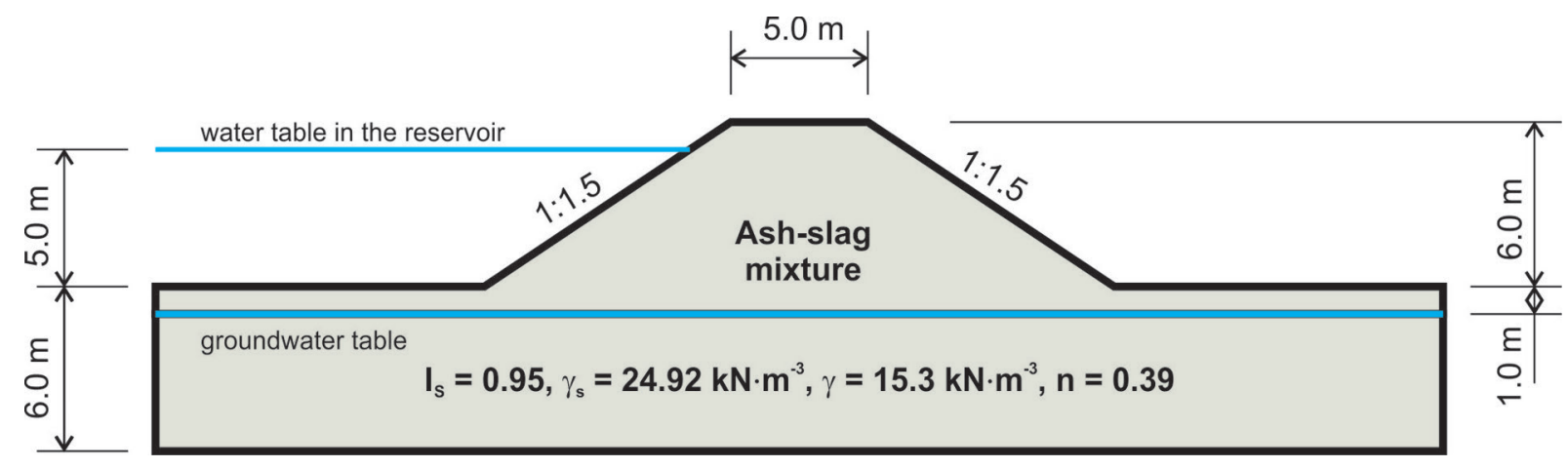

Fig. 2. Diagram of the computational model of the embankment formed of the ash-slag mixture with a slope gradient of 1:1.5 
Computations of unsteady flow were based on the assumption that the water level in the reservoir adjacent to the embankment would suddenly rise from the position of the groundwater table $1 \mathrm{~m}$ to $5 \mathrm{~m}$ above the level of its base. In order to test the variability of the position of the filtration curve and to determine the time required to attain a steady flow, the saturation limit was calculated while water was rising in the reservoir after $0.5,1,7,28,56,90,120,150,180$ and 360 days. It was assumed that the ash-slag mixture had the same hydraulic properties in the vertical and horizontal directions. The parameters of the van $\mathrm{Ge}$ nuchten equation were $\alpha=2.54045$ and $n=3.5002$ and were calculated in RETC software.

Earlier research (Zawisza 2001, Gruchot \& Resiuła 2011, Gruchot 2016) has shown that an ash-slag mixture has high shear strength values, largely due to of the sharp-edged grains of the mixtures, despite determination of these parameters using intermediate frames. Another factor affecting the stability of the slopes is damming of the water or other liquid substances for which the embankment is created.

Given the above, the stability of the embankment was calculated for the following variants:

- shear strength values obtained from the test without submersion of the shearing zone and without water filtration,

- shear strength values obtained from the test with submersion of the shearing zone and steady water flow through the embankment with an upper water surface at a level of 5.0 above the base of the slope.

The procedure for computing steady and unsteady flow and stability was described in detail by Gruchot (2016).

\section{RESULTS AND DISCUSSION}

According to the Catalogue of Waste (Rozporzadzenie Ministra Srodowiska... 2014), the analysed waste was classified as an ash-slag mixture from wet disposal of combustion waste with code 1001 80 , belonging to the group of waste other than neutral and hazardous waste.

\section{Physicochemical properties}

The mean content of heavy metals in the eluate was relatively low and can be ordered in the following decreasing series: $\mathrm{Cr}>\mathrm{Zn}>\mathrm{Cu}>\mathrm{Pb}>\mathrm{Cd}$. Among the physicochemical properties tested, $\mathrm{Cd}, \mathrm{K}, \mathrm{Ca}, \mathrm{pH}$, and conductivity had very low variation coefficients. This measure of variability was also low for the concentrations of other elements, i.e. $\mathrm{Pb}, \mathrm{Zn}, \mathrm{Cu}, \mathrm{Cr}, \mathrm{Na}$ and $\mathrm{Mg}$ (Tab. 1). The lack of distinct variation in the properties of the waste indicates the homogeneity of its chemical composition irrespective of the part of the landfill on which it was deposited, which is of great importance for its potential utilization, which will be considered below. Dhananjay et al. (2010) found comparably low concentrations of metals in eluates of ash from a power plant in Bhusawal (India). Popescu et al. (2013) also reported low content of $\mathrm{Cd}, \mathrm{Cu}, \mathrm{Cr}, \mathrm{Pb}$ and $\mathrm{Zn}$ in eluates from an ash-slag mixture from a landfill in the Ceplea Valley (Romania). Literature reports indicate that the low leachability of these elements is due to their concentration in structures of stable aluminosilicate phases (Kapuściński \& Strzałkowska 2005, Rosik-Dulewska \& Karwaczyńska 2008). The leachability of these elements is also influenced by the $\mathrm{pH}$ of the eluate. In the initial period of the deposition of an ash-slag mixture it is usually high $(9 \leq \mathrm{pH} \leq 12)$, and then, as a result of binding reactions taking place in the waste, it decreases to approach neutral $(6.5 \leq \mathrm{pH} \leq 7.8)$ (Klojzy-Karczmarczyk \& Mazurek 2003, Woźniak \& Klisik 2007, Adamczyk \& Nowak 2012). The $\mathrm{pH}$ of the eluates from the former CEZ Skawina Power Plant landfill was close to the neutral $\mathrm{pH}$ (Tab. 1) characteristic of ash after a long storage period. Adamczyk and Skrzypczak (2004), in a study of eluate from fresh ash from the Opole Power Plant, found higher concentrations of $\mathrm{Cd}, \mathrm{Co}, \mathrm{Cr}, \mathrm{Mn}, \mathrm{Ni}$ and $\mathrm{Zn}$ than in the case of ash stored for a year. They also observed that a slightly acidic $\mathrm{pH}$ is conducive to the leaching of lead and iron compounds from ash, and copper compounds are intensively leached into the solution at $\mathrm{pH}=7-8$. Similar correlations have been noted for chromium, which solubility increases with the $\mathrm{pH}$ of the eluate $(\mathrm{Ku}-$ cowski et al. 1997). 
Table 1

Physicochemical properties of eluates from the ash-slag mixture

\begin{tabular}{|c|c|c|c|c|c|c|c|c|}
\hline \multirow{3}{*}{ Element } & \multirow{3}{*}{ Unit } & \multicolumn{7}{|c|}{ Value } \\
\hline & & \multirow{2}{*}{ minimum } & \multirow{2}{*}{ maximum } & \multicolumn{2}{|c|}{ mean } & \multirow{2}{*}{ median } & \multirow{2}{*}{ SD } & \multirow{2}{*}{ V\% } \\
\hline & & & & arithmetic & geometric & & & \\
\hline $\mathrm{Cd}$ & \multirow{5}{*}{$\mu \mathrm{g} / \mathrm{dm}^{-3}$} & $<0.4$ & $<0.4$ & $<0.4$ & $<0.4$ & $<0.4$ & 0.00 & 0.00 \\
\hline $\mathrm{Pb}$ & & 0.79 & 1.46 & 1.12 & 1.11 & 1.13 & 0.18 & 16.07 \\
\hline $\mathrm{Zn}$ & & 5.10 & 7.59 & 6.51 & 6.47 & 6.64 & 0.74 & 11.37 \\
\hline $\mathrm{Cu}$ & & 2.13 & 3.99 & 2.74 & 2.70 & 2.56 & 0.50 & 18.25 \\
\hline $\mathrm{Cr}$ & & 6.02 & 9.93 & 7.65 & 7.58 & 7.86 & 1.04 & 13.59 \\
\hline $\mathrm{Na}$ & \multirow{4}{*}{$\mathrm{mg} / \mathrm{dm}^{-3}$} & 10.11 & 14.94 & 12.85 & 12.75 & 13.04 & 1.59 & 12.37 \\
\hline $\mathrm{K}$ & & 15.70 & 20.94 & 18.74 & 18.68 & 19.10 & 1.50 & 8.00 \\
\hline $\mathrm{Ca}$ & & 50.30 & 67.20 & 60.79 & 60.63 & 61.80 & 4.31 & 7.09 \\
\hline $\mathrm{Mg}$ & & 25.80 & 39.80 & 32.35 & 32.11 & 31.45 & 3.97 & 12.27 \\
\hline $\mathrm{pH}$ & - & 6.50 & 6.80 & 6.60 & 6.59 & 6.60 & 0.10 & 1.52 \\
\hline Conductance & $\mu \mathrm{S} / \mathrm{cm}^{-1}$ & 445.00 & 460.00 & 452.30 & 452.28 & 452.00 & 3.91 & 0.86 \\
\hline
\end{tabular}

\section{Physical and mechanical properties}

According to the geotechnical nomenclature (PNEN ISO 14688-2: 2006), the ash-slag mixture was classified as silty sand composed of several fractions (siSa). The sand fraction was dominant, constituting about $64 \%$ of the grain-size composition, while the silt fraction accounted for $21 \%$ and the clay fraction about $2 \%$ (Tab. 2). The content of the gravel fraction did not exceed $14 \%$.

The average specific density was $2.54 \mathrm{~g} \cdot \mathrm{cm}^{-3}$. The maximum dry density averaged $1.26 \mathrm{~g} \cdot \mathrm{cm}^{-3}$ at an optimum moisture content of about $31 \%$. Passive capillarity was $0.45 \mathrm{~m}$ and the sand equivalent was $49 \%$.

Table 2

Geotechnical characterization of the ash-slag mixture

\begin{tabular}{|c|c|c|c|}
\hline \multicolumn{3}{|c|}{ Parameter } & Value \\
\hline \multicolumn{3}{|l|}{$\begin{array}{l}\text { Content of fraction [\%]: } \\
\text { - gravel Gr: } 63 \div 2 \mathrm{~mm} \\
\text { - } \text { sand Sa: } 2 \div 0.063 \mathrm{~mm} \\
\text { - } \text { silt Si: } 0.063 \div 0.002 \mathrm{~mm} \\
\text { - } \text { clay } \mathrm{Cl}:<0.002 \mathrm{~mm}\end{array}$} & $\begin{array}{c}13.7 \\
63.5 \\
21.1 \\
1.7\end{array}$ \\
\hline \multicolumn{3}{|c|}{ Name according to (PN-EN ISO 14688-2:2006) } & $\begin{array}{c}\text { siSa } \\
\text { (silty sand) }\end{array}$ \\
\hline \multicolumn{2}{|l|}{ Content of particles [\%]: } & $\begin{array}{l}\leq 0.075 \mathrm{~mm} \\
\leq 0.02 \mathrm{~mm}\end{array}$ & $\begin{array}{l}24.5 \\
12.0 \\
\end{array}$ \\
\hline \multicolumn{3}{|l|}{ Uniformity coefficient [-] } & 13.5 \\
\hline \multicolumn{3}{|l|}{ Specific gravity $\left[\mathrm{Mg} \cdot \mathrm{m}^{-3}\right]$} & 2.54 \\
\hline \multicolumn{3}{|l|}{ Optimum moisture content [\%] } & 31.6 \\
\hline \multicolumn{3}{|l|}{ Maximum bulk density $\left[\mathrm{Mg} \cdot \mathrm{m}^{-3}\right]$} & 1.26 \\
\hline \multicolumn{3}{|l|}{ Passive capillarity $[\mathrm{m}]$} & 0.45 \\
\hline \multicolumn{3}{|l|}{ Sand equivalent $[-]$} & 48.6 \\
\hline \multirow{2}{*}{$\begin{array}{l}\text { Internal friction angle }\left[^{\circ}\right] \text { for } \\
\text { degree of compaction } I_{S}=0.95\end{array}$} & \multicolumn{2}{|l|}{ without submersion } & 40.1 \\
\hline & \multicolumn{2}{|l|}{ with submersion } & 17.5 \\
\hline \multirow{2}{*}{$\begin{array}{l}\text { Cohesion }[\mathrm{kPa}] \text { for degree of } \\
\text { compaction } I_{S}=0.95\end{array}$} & \multicolumn{2}{|l|}{ without submersion } & 21.5 \\
\hline & \multicolumn{2}{|l|}{ with submersion } & 5.6 \\
\hline \multicolumn{3}{|c|}{$\begin{array}{l}\text { Coefficient of permeability } k_{10}\left[\mathrm{~m} \cdot \mathrm{s}^{-1}\right] \text { for degree of compaction } \\
I_{S}=0.95\end{array}$} & $9.5 \cdot 10^{-7}$ \\
\hline
\end{tabular}


The obtained values of the specific density of solid particles were within the range given by Pisarczyk (2004) - from 1.59 to $2.74 \mathrm{~g} \cdot \mathrm{cm}^{-3}$. Kucowski et al. (1997) report that the passive capillarity of ash-slag mixtures can range from 1.2 to $3.0 \mathrm{~m}$, so in the case of the mixture in question the value of this parameter was much lower than the given range. On the other hand, the values of maximum dry density of solid particles and optimum moisture content indicate the good compactibility of the tested ash-slag mixture.

The values for the angle of internal friction and cohesion of the ash-slag mixture were high and depended on the test method. Submersion of the shearing zone caused an approximately 2 -fold reduction in the internal friction angle and a nearly 4 -fold reduction in cohesion (Tab. 2).

\section{Calculations of unsteady flow}

The calculations showed significant variation over time in the saturation limit and thus in the flow volume as compared to the initial state, in which only the groundwater table existed. Figure 3 illustrates the saturation limit for the embankment with a slope gradient of 1:1.5 after 1, 7, 28 and 180 days.
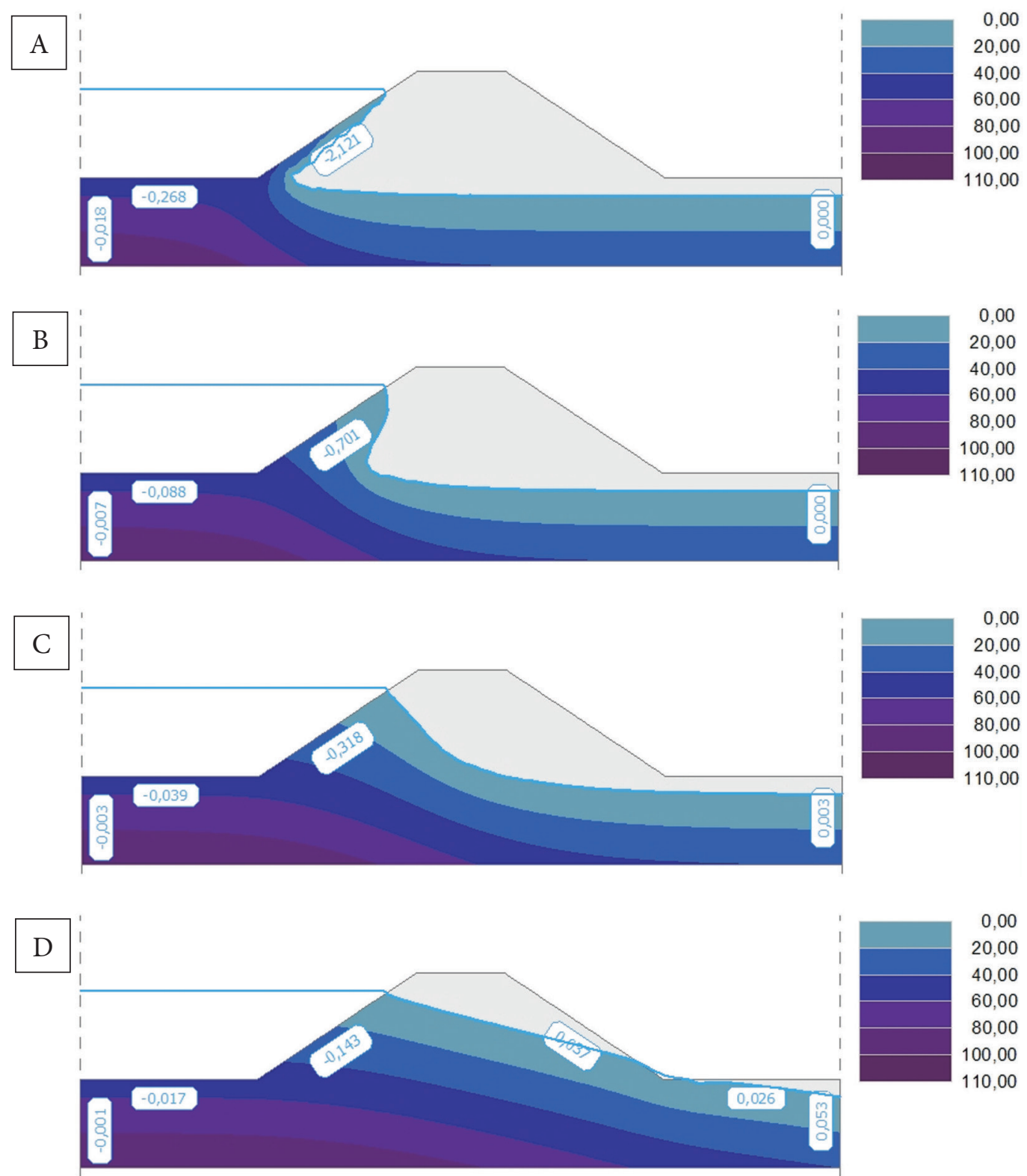

Fig. 3. Saturation limit (filtration curve) with changes in pore pressure in conditions of unsteady filtration for the embankment with a slope gradient of $1: 1.5$ from Geo5: A) $t=1$ day; B) $t=7$ days; C) $t=28$ days; $D) t=180$ days 
The calculations show that the same values were not obtained for the volume of water flowing to and from the embankment (Fig. 4), which was due to the mixture's low coefficient of permeability.
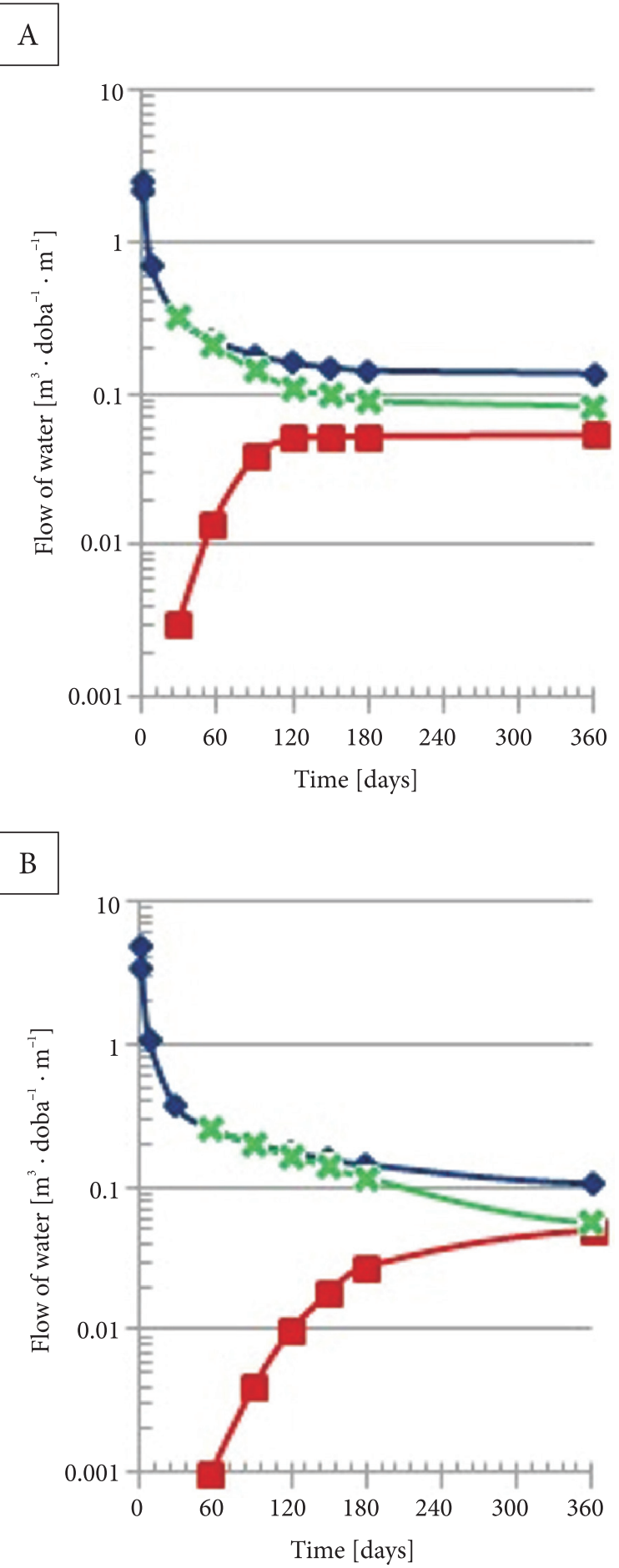

Fig. 4. The dependence of water flow through the model embankment on time from calculations of unsteady filtration in Geo5: A) slope gradient 1:1.5; B) slope gradient 1:3
It can be assumed, however, that conditions of steady water flow were obtained after about 120 days in the case of the embankment with a slope gradient of 1:1.5 and after about 180 for the embankment with a slope gradient of 1:3 from the moment the water level rose in the reservoir. This is due to the stabilization of the difference in values for incoming and outgoing water. The values obtained for unsteady flow after 360 days were largely consistent with the calculations for steady flow used to calculate the stability of the embankment.

\section{Stability calculations}

The stability factor calculated in the absence of the damming of the water, i.e. taking into account only the groundwater table and the shear strength parameters without submersion of the shearing zone was very high (Fig. 5). This indicates that the ash-slag mixture can be successfully used for the construction of earth structures. It should be noted, however, that the stability factor calculated for the model with the lower slope gradient (1:3) was significantly lower, by about $20 \%$.

The course of the filtration curve for conditions of steady flow through the embankment with the water table in the tank at a level of 5.0 $\mathrm{m}$ above the base of the embankment is presented in Figure 6. This course is typical for earth embankments without drainage, with outflow of water onto the slope. It also indicates that the shift in the saturation limit below the surface of the embankment base occurred a few meters from the foot of the downstream slope. The stability calculations taking into account steady flow and shear strength parameters with the submersion of the shearing zone showed that the downstream slope would be unsteady, because the stability factor was less than 1.0. This indicates the need to additionally secure the upstream slope if it is to be used for engineering purposes, which would limit infiltration of water into the embankment. 


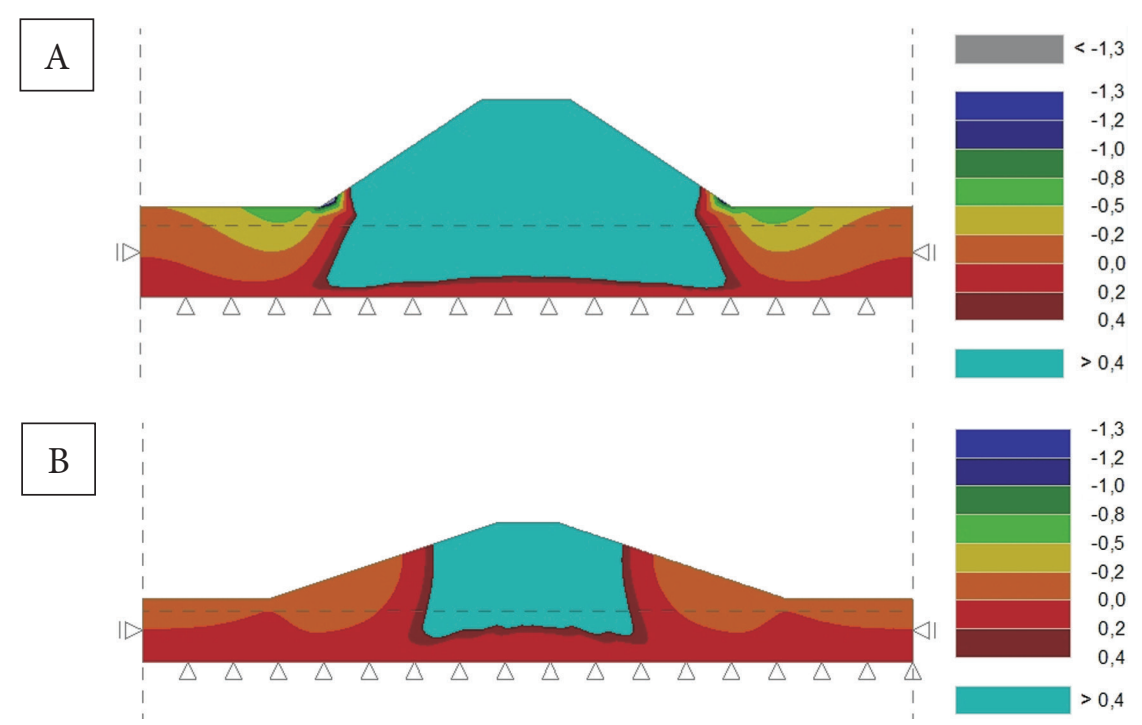

Fig. 5. Deformations of the ash-slag mixture embankment for shear strength parameters without submersion of the shearing zone and without damming of the water from Geo5: A) slope gradient 1:1.5, FS =3.23; B) slope gradient 1:3, FS =2.57

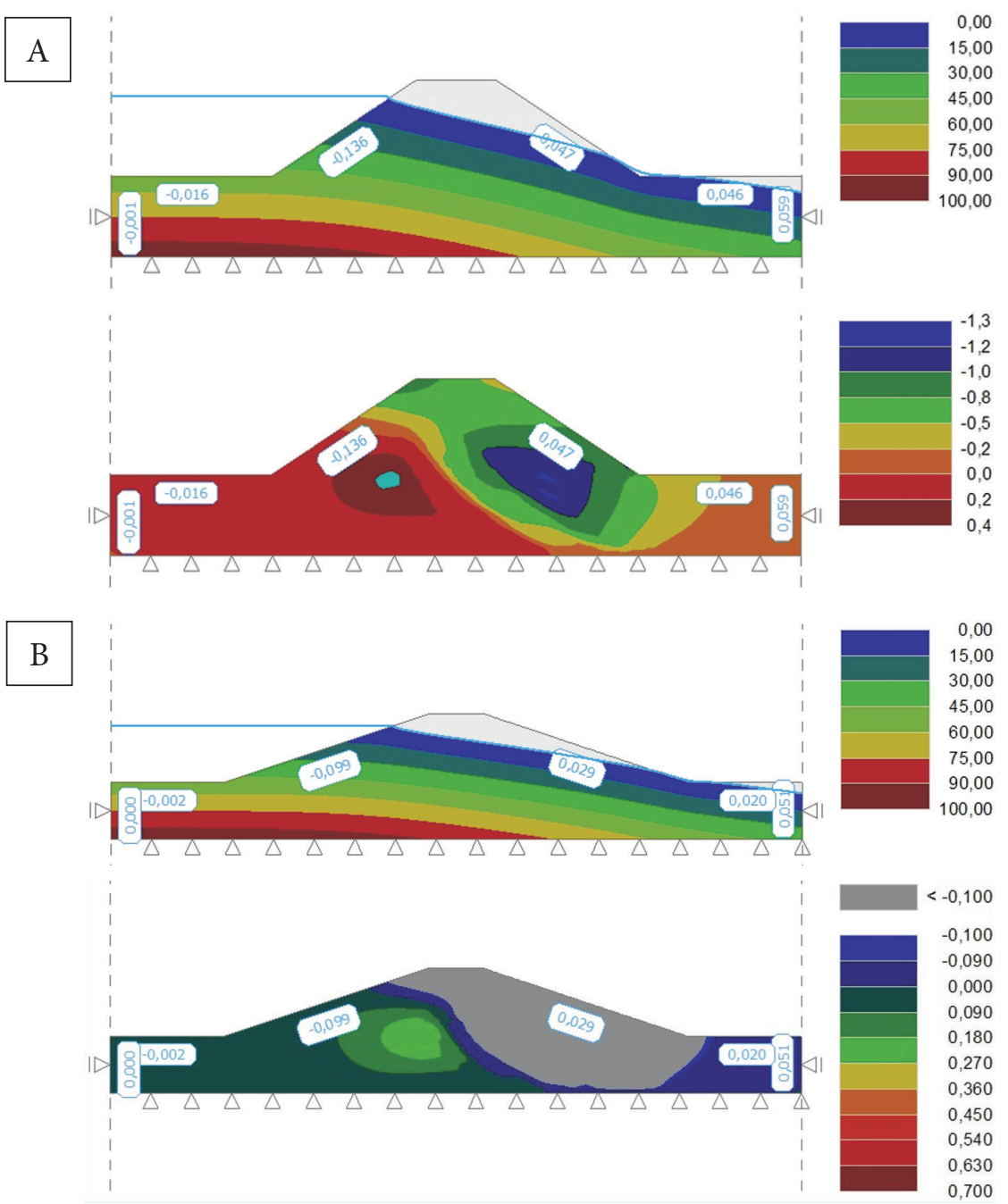

Fig. 6. Course of the filtration curve in conditions of steady flow and deformations of the ash-slag mixture embankment for shear strength parameters with submersion of the shearing zone from Geo5: A) slope gradient 1:1.5, course of filtration curve, steady flow; B) slope gradient 1:1.5, displacements $d x, F S=0.81$; C) slope gradient 1:3, course of filtration curve, steady flow; D) slope gradient 1:3, displacements $d x, F S=0.90$ 


\section{Evaluation of the mixture's suitability for construction engineering purposes}

The suitability of the ash-slag mixture for construction engineering purposes was evaluated in terms of its use for the expansion of a local road network, which would help to increase the utilization of the mixture. The application of this waste can also be considered for ongoing conservation work at the embankment of the Vistula river and the Łączany-Skawina river channel.

Due to the direct proximity of these watercourses, which should be considered as potential recipients of any leachates, the effect of the eluates on surface water quality was assessed. According to the applicable law (Rozporzadzenie Ministra Srodowiska... 2016), the eluates should be considered to pose no threat to surface water quality in terms of the concentrations of basic elements, i.e. $\mathrm{Na}, \mathrm{K}, \mathrm{Ca}$ and $\mathrm{Mg}$, of metals considered particularly harmful, i.e. $\mathrm{Zn}, \mathrm{Cu}$ and $\mathrm{Cr}$, or of priority metals, $\mathrm{Cd}$ and $\mathrm{Pb}$. The content of these elements also does not exceed the permissible concentrations for groundwater given in (Rozporzadzenie Ministra Srodowiska... 2008). The conductance and $\mathrm{pH}$ of the eluates are also in compliance with the above-mentioned laws.

Standard PN-S-02205:1998 classifies ash-slag mixtures as materials suitable for earth structures when they meet the applicable requirements of this standard. In the case of the mixture from the CEZ Skawina Power Plant, the content of the sand and gravel fraction was about $77 \%$, which was over twice as high as the minimum required value, while the content of grains smaller than $0.075 \mathrm{~mm}$ was about $25 \%$, which was three times lower than the maximum permissible values. The angle of internal friction was over two times higher than required. The maximum dry density was nearly $0.3 \mathrm{~g} \cdot \mathrm{cm}^{-3}$ higher than the required value, passive capillarity was nearly $1.5 \mathrm{~m}$ lower than the acceptable limit, and linear swelling was negligible. Thus the ash-slag mixture at optimal moisture content meets the requirements of the standard (PN-S-02205:1998). The sand equivalent of the mixture, which was about $49 \%$, and the passive capillarity of $0.4 \mathrm{~m}$ allow the mixture to be classified among nonswelling soils.
The stability calculations performed with and without the damming of the water at shear strength values obtained under conditions with and without submersion of the shearing zone indicate that the embankment would be stable provided that it is protected from water. Assuming the embankment made from the mixture under investigation and that it will be an element of passive protection, and thus the damming of the water will only occur in exceptional (emergency) situations, the use of this mixture is advisable. The filtration calculations performed in conditions of unsteady flow showed that damming of the water would have to continue for at least a few months to attain a saturation limit (filtration curve) for steady conditions, which in a situation of passive protection should not occur.

\section{CONCLUSIONS}

The following conclusions can be drawn from the analysis of the test results for the ash-slag mixture from the former CEZ Skawina Power Plant landfill in Kopanka and the stability calculations for an embankment created from it:

1. The eluates tested indicate that the mixture will not jeopardize surface water quality in terms of the concentrations of basic, hazardous or priority elements. The content of these elements also does not exceed permissible concentrations for groundwater.

2. The conductance and $\mathrm{pH}$ of the eluates are in compliance with current laws.

3. The mixture has favourable geotechnical parameters which are significantly dependent on moisture content.

4. The slope stability calculations for embankments created from the mixture at optimum moisture content and high compaction $\left(I_{S} \geq 0.95\right)$ indicate that they will be stable even in the case of high gradients (1:1.5). The slopes will be unstable in conditions of submersion, which should not occur if we assume the embankment will be used for passive flood protection.

5. The results of the tests and slope stability calculations confirm that the ash-slag mixture is highly suitable for the purposes of the construction of earth structures, provided that they are isolated from water. 
The research work was financed from DS 3337/ KEKOP/2017.

\section{REFERENCES}

Adamczyk Z. \& Nowak J., 2012. Zmiana składu chemicznego żużli paleniskowych w składowisku izolowanym od środowiska. Górnictwo i Geologia, 7, 2, 7-21.

Adamczyk Z. \& Skrzypczak K., 2004. Wymywanie metali ciężkich z popiołów lotnych Elektrowni Opole w zależności od $\mathrm{pH}$ roztworów ługujących. Ochrona Powietrza i Problemy Odpadów, 6, 215-219.

Dhananjay B.S., Ramanand N.J., Vasimshaikh A.K., Sopan T.I. \& Sanjay B.A., 2010. Extraction and Leaching of Heavy Metals from Thermal Power Plant Fly Ash and Its Admixtures. Polish Journal of Environmental Studies, $19,6,1325-1330$.

Environment, Statistical Information and Elaborations 2016. Polish Central Statistical Office, Warsaw.

Fenelonov V.B., Mel'gunov M.S. \& Parmon V.N., 2010. The properties of cenospheres and the mechanism of their formation during high-temperature coal combustion at thermal power plants. KONA Power and Particle Journal, 28, 189-208.

Galos K. \& Uliasz-Bocheńczyk A., 2005. Źródła i użytkowanie popiołów lotnych ze spalania węgli w Polsce. Gospodarka Surowcami Mineralnymi, 1, 23-42.

Góra E., 1986. Wpływ popiołów z węgla kamiennego na plonowanie roślin. Zeszyty Naukowe Akademii Rolniczej im. H. Kołłątaja w Krakowie. Rozprawa Habilitacyjna, 101, AR, Kraków.

Gruchot A., 2016. Utylizacja odpadów poweglowych i poenergetycznych do celów inżynierskich jako czynnik ksztattowania i ochrony środowiska. Zeszyty Naukowe Uniwersytetu Rolniczego w Krakowie. Rozprawy, 410, Wydawnictwo Uniwersytetu Rolniczego, Kraków.

Gruchot A. \& Resiuła E., 2011. Wpływ zagęszczenia i nawodnienia na wytrzymałość na ścinanie mieszaniny popiołowo-żużlowej i stateczność wykonanego z niej nasypu. Górnictwo i Geoinżynieria, 2, 257-264.

Haustein E. \& Quant B., 2011. Charakterystyka wybranych właściwości mikrosfer - frakcji popiołu lotnego - ubocznego produktu spalania węgla kamiennego. Gospodarka Surowcami Mineralnymi, 27, 3, 95-111.

Hirajima T., Petrus H.T., Oosako Y., Nonaka M., Sasaki K. \& Ando T., 2010. Recovery of cenospheres from coal fly ash using a dry separation process: Separation estimation and potential application. International Journal of Mineral Processing, 95, 1-4, 18-24.

Hycnar J. \& Tora B., 2015. Analiza zawartości wybranych metali w węglach i produktach ich spalania. Cuprum Czasopismo Naukowo-Techniczne Górnictwa Rud, 2, 75, 157-168.

Jarosiński A., 2016. Możliwości pozyskiwania metali ziem rzadkich w Polsce. Zeszyty Naukowe Instytutu Gospodraki Surowcami Mineralnymi i Energia PAN, 92, 75-88.

Jayaranjan M.L.D., van Hullebusch E.D. \& Annachhatre A.P., 2014. Reuse options for coal fired power plant bottom ash and fly ash. Reviews Environmental Science and Bio-Technology, 13, 4, 467-486.
Kapuściński T. \& Strzałkowska E., 2005. Ługowalność pierwiastków podstawowych i śladowych z odpadów paleniskowych lokowanych w wyrobiskach górniczych. Gospodarka Surowcami Mineralnymi, 3, 37-46.

Klojzy-Karczmarczyk B. \& Mazurek J., 2003. Wpływ odcieków ze składowiska odpadów komunalnych i przemysłowych na jakość środowiska wodnego. Czasopismo Techniczne, 94-97, 5-12.

Kucowski J., Laudyn D. \& Przekwas M., 1997. Energetyka a ochrona środowiska. Wyd. 4. Wydawnictwa Naukowo Techniczne, Warszawa.

Kušnierová M., Praščáková M., Čablik V. \& Fečko P., 2011. Odpady energetyczne jako substytut niemetalicznych surowców pierwotnych [Energetic waste as an equivalent for primary nonmetallic materials]. Inżynieria $\mathrm{Mi}$ neralna [Journal of the Polish Mineral Engineering Socie$t y], 12,1,73-78$.

PN-EN 12457-4:2006. Charakteryzowanie odpadów - Wymywanie - Badanie zgodności w odniesieniu do wymywania ziarnistych materiałów odpadowych i osadów - Część 4: Jednostopniowe badanie porcjowe przy stosunku cieczy do fazy stałej $10 \mathrm{l} / \mathrm{kg} w$ przypadku materiałów o wielkości czastek poniżej $10 \mathrm{~mm}$ (bez redukcji lub $z$ redukcja wielkości). Polski Komitet Normalizacyjny, Warszawa.

PN-EN ISO 14688-2:2006. Badania geotechniczne - Oznaczanie i klasyfikowanie gruntów - Część 2: Zasady klasyfikowania. Polski Komitet Normalizacyjny, Warszawa.

PN-S-02205:1998. Drogi samochodowe - Roboty ziemne Wymagania i badania. Polski Komitet Normalizacyjny, Warszawa.

Pisarczyk S., 2004. Grunty nasypowe. Właściwości geotechniczne i metody ich badania. Oficyna Wydawnicza Politechniki Warszawskiej, Warszawa.

Popescu L., Cruceru M., Predeanu G., Volceanov E., Abagiu T., Bălănescu M., Popa R. \& Schiopu E.C., 2013. Assessment of heavy metal content and leaching characteristics of ash from a coal-fired power plant in Romania. [in:] Recent Researches in Electric Power and Energy Systems: Proceedings of the $13^{\text {th }}$ International Conference on Electric Power Systems, High Voltages, Electric Machines (POWER'13) \& Proceedings of the $1^{\text {st }}$ International Conference on Power and Energy Systems (POES'13) Chania, Crete Island, Greece, August 27-29, 2013, WSEAS Press, 250-255.

Ram L., Srivastava N., Jha S., Sinha A., Masto R. \& Selvi V., 2007. Management of lignite fly ash for improving soil fertility and crop productivity. Environmental Management, 40, 3, 438-452.

Referat Ochrony Środowiska Elektrowni Skawina S.A. 2012. Charakterystyka składowiska odpadów paleniskowych Elektrowni Skawina [typescript].

Rosik-Dulewska Cz. \& Karwaczyńska U., 2008. Metody ługowania zanieczyszczeń z odpadów mineralnych $\mathrm{w}$ aspekcie możliwości ich zastosowania w budownictwie hydrotechnicznym. Rocznik Ochrona Środowiska [Annual Set The Environment Protection], 10, 205-219.

Rozporzadzenie Ministra Środowiska z dnia 23 lipca 2008 r. w sprawie kryteriów i sposobu oceny stanu wód podziemnych. Dz.U. 2008, nr 143 poz. 896.

Rozporządzenie Ministra Środowiska z dnia 9 grudnia 2014 r. w sprawie katalogu odpadów. Dz.U. 2014, poz. 1923. 
Rozporządzenie Ministra Środowiska $z$ dnia 21 lipca 2016 r. w sprawie sposobu klasyfikacji stanu jednolitych cześci wód powierzchniowych oraz środowiskowych norm jakości dla substancji priorytetowych. Dz.U. 2016, poz. 1187.

Woźniak M. \& Klisik A., 2007. Wpływ na wody gruntowe odcieków ze składowisk popiołowych. [in:] Materiały Krakowskiej Konferencji Młodych Uczonych 2007: Kraków, 20-22 września 2007, Sympozja i Konferencje KKMU, 2, Fundacja Studentów i Absolwentów
Akademii Górniczo-Hutniczej “Academica”, Grupa Naukowa Pro Futuro, Kraków, 369-376.

Zawisza E., 2001. Geotechniczne i środowiskowe aspekty uszczelniania grubookruchowych odpadów poweglowych popiołami lotnymi. Zeszyty Naukowe Akademii Rolniczej im. H. Kołłątaja w Krakowie. Rozprawy, 280, Wyd. AR, Kraków.

Żygadło M. \& Woźniak M., 2009. Obserwacje zmian właściwości popiołów powęglowych w procesach wietrzeniowych. Energetyka i Ekologia, 11, 771-775. 